\title{
Comparative Study of Soil Microbial Dynamics under Forest and Agricultural Lands of Cooch Behar District of West Bengal, India
}

\author{
Munmun Majhi ${ }^{1 *}$, Deo Kumar ${ }^{1}$, Vivek Kumar ${ }^{2}$ and Abhishek Ranjan ${ }^{2}$ \\ ${ }^{1}$ Department of Soil Science and Agricultural Chemistry, Uttar Banga Krishi Viswavidyalaya, \\ Cooch Behar, West Bengal, 736165, India \\ ${ }^{2}$ Department of Soil Science and Agricultural Chemistry, Dr.Rajendra Prasad Central \\ Agricultural University, Pusa, Samastipur, Bihar, 848125, India \\ *Corresponding author
}

\section{A B S T R A C T}

\section{Keywords}

Soil C, Forest soil, Agricultural soil, Soil respiration, Microbial biomass carbon

Article Info

Accepted:

18 March 2020

Available Online:

10 April 2020
The study of soil microbial dynamics is a matter of importance as microbial activities controls soil carbon $(C)$ and nutrient dynamics. This study focused on soil $\mathrm{C}$ budgeting under forest and cultivated lands as land use affect soil $\mathrm{C}$ and microbial dynamics. The soil samples were collected from Rasomoti and Sonapur forest range along with the agricultural fields of the neighbouring areas. Among soil microbial parameters, microbial biomass $\mathrm{C}$ and soil respiration were studied. Outcomes indicated that Microbial biomass $\mathrm{C}(\mathrm{Cmic})$ and soil respiration $(\mathrm{Cmin})$ were found higher in forest soils. Higher $\mathrm{C}$ as food and energy source for soil microorganisms in the forest soils was the possible reason. However, higher microbial quotient (MQ) was observed in agricultural soils. It indicated that quantitatively arable soils had lower $\mathrm{C}$ stock but that $\mathrm{C}$ was in more labile and available condition. Less aggregation of soils under tillage might be the possible reason.

\section{Introduction}

Soil health and soil $\mathrm{C}$ cycle of any ecosystem largely depend on the soil microorganisms, which play a vital role in the soil processes (Brockett, 2012). Soil enzymes play a very significant role in the mineralisation process and help in the nutrient uptake by the plants (Sardans and Penuelas, 2005).The activity of the soil microbes characteristics depend on soil moisture and organic $\mathrm{C}$ quality while the enzymatic activities of this microbial community determines soil $\mathrm{C}$ dynamics. For example, potential activity of phenol oxidase and peroxidase were highest in mineral arable soil but the activity of phosphatase and the $\beta$ glucosidase were found highest in forest floors (Brockett, 2012). The composition of 
soil microbial community depends on many factors like the precipitation, types of vegetation, $\mathrm{C}$ input etc. (Castro, 2010). It has been also studied that the enzymes activities are higher during spring than in autumn season (Sardans and Penuelas, 2005). The common enzymatic essays used for measuring microbial activity are generally esterase, phosphatase and dehydrogenase (Sinsabaugh, 1994). The parameters like soil $\mathrm{pH}$, organic $\mathrm{C}$, humic compound content, microbial biomass and enzymatic activities generally decrease with the depth but in many cases it is found that actinomycetes biomass gets decreased with the depth (Snajdr et al., 2008).

The $\mathrm{C}, \mathrm{N}$ and $\mathrm{P}$ cycle in the soil is affected by the urease, dehydrogenase, aryl-sulphatase, beta-glucosidase and acid phosphatase (Salazar et al., 2011).The soil C storage is highly influenced by the plant diversity (Lange et al., 2015). Land use also affects soil $\mathrm{C}$ and microbial dynamics. The conversion of forest land into other land use system decreases the amount of soil nutrient and the microbial C (Srivastava and Singh, 1991). The exudation of $\mathrm{C}$ by root of the plants triggers the microbial activity and stimulates the production of extracellular enzymes in the rhizosphere (Brzostek, 2013).

The Soil enzymatic activity indicates about the metabolic requirement of the soil community and the available nutrients (Caldwell, 2005).The availability of $\mathrm{C}$ in soil for the microbial community depends on seasonal cycle of plants and there is a relationship between the composition of microbial community and the enzymatic activity over the seasonal course (Kaiser, 2010). For example, the phenol oxidase and peroxidase were highest in late summer whereas cellulase and protease were highest during late autumn (Kaiser, 2010). The plant diversity increases rhizosphere $\mathrm{C}$ input resulting into increase in microbial activity and soil C storage (Lange, 2015). It has also been reported that addition of $\mathrm{N}$ into soil decreases microbial respiration rate and soil microbial biomass (Ramirez, 2012).

The activity of soil enzymes is directly proportional to the microbial respiration and soil total biomass (Frankenberger and Dick, 1983). Out of total soil respiration, underground root contributes $50.5 \%$ while the rest is contributed by the fungal and bacterial biomass by $44 \%$ and $5.5 \%$ respectively (Behara, 1990). The C quality of any soil is influenced by the ratios like Cmic to soil total organic C (Srivastava and Singh, 1991).

\section{Materials and Methods}

\section{Study area}

This study was conducted in northern part of Cooch Behar District of West Bengal, India. In order to fulfill the objective of the present study, forest (natural as well as plantation) and agricultural land use were considered for soil sampling. Rasomati forest (tropical moist semi-evergreen forest), located at $26^{\circ} 27^{\prime} \mathrm{N}$ latitude and $88^{\circ} 19^{\prime} \mathrm{E}$ longitude with an elevation of $66 \mathrm{~m}$ above mean sea level, was selected for collection of forest soil samples.

This area comes under Pundibari forest range of Cooch Behar forest division, at the foothills of sub-Himalayan mountain belts. The agricultural lands were selected from the nearby villages. The average minimum and maximum temperature of this area varied from $23^{\circ} \mathrm{C}$ during winter (January) to $33^{\circ} \mathrm{C}$ during summer (July) (data of nearest station as obtained from ClimWat). On an average, the annual rainfall varies from $2000 \mathrm{~mm}$ to $3500 \mathrm{~mm}$, bulk of which is being received during pre-monsoon and monsoon period i.e. May to September. This area belongs to warm and humid climate except a short spell of winter extending from December to February. 


\section{Soil sampling}

Soil sampling was done in the month of March, 2018 (pre-monsoon) from the forest and cultivated lands. 14 soil samples were collected from these forests while 13 were collected from arable lands. Composite sampling (5 samples for a soil samples) was done. To exactly determine the sampling locations, hand-held GPS receiver (Garmin, Olathe, KS, USA) was used.

\section{Soil analysis}

A part of soil samples were kept in the refrigerator for the analysis of the biological parameter and the rest of the soils were air dried. This air dried soil was then passed through $5 \mathrm{~mm}$ sieve (used for aggregate analysis) and $2 \mathrm{~mm}$ sieve (used for physicochemical analysis).

\section{Estimation of microbial biomass C}

Field moist soil samples ( $25 \mathrm{~g})$, stored at $4^{\circ} \mathrm{C}$, were exposed to $\mathrm{CHCl} 3$ vapour for 24 hours and extracted with $0.5 \mathrm{M} \mathrm{K} 2 \mathrm{SO} 4$. A second non-fumigated set of samples was also extracted under similar conditions. The difference between $\mathrm{C}$ obtained from the fumigated and from the non-fumigated ones was taken to represent the microbial $\mathrm{C}$ flush and converted to $\mathrm{Cmic}$ using the relationship: $\mathrm{C} m i c=1 / 0.41 \times$ C-flush (Voroney and Paul, 1984). All results are expressed on an oven dry soil basis $\left(105^{\circ} \mathrm{C}, 24 \mathrm{~h}\right)$ and are the means of three replicate analyses.

\section{Determination of soil respiration $\left(\mathrm{CO}_{2}-\mathrm{C}\right.$ release)}

Field moist soil samples, stored at $4^{\circ} \mathrm{C}$, were used for estimation of $\mathrm{CO} 2-\mathrm{C}$ release from soil or soil respiration. For analysis of $\mathrm{CO} 2-\mathrm{C}$ release, $50 \mathrm{~g}$ field-moist soil samples were rewetted to $50 \%$ water- filled pore space and then placed in $1 \mathrm{~L}$ canning jars along with vials containing $10 \mathrm{~mL}$ of $0.5 \mathrm{~N} \mathrm{NaOH}$ to trap the evolved $\mathrm{CO} 2$ and incubated for 23days at $27 \pm 2{ }^{\circ} \mathrm{C}$. Alkali traps were replaced at $3^{\text {rd }}$, $6^{\text {th }}, 13$ thand finally removed at $23^{\text {rd }}$ day. Evolved $\mathrm{CO} 2$ had been converted to $\mathrm{Na} 2 \mathrm{CO} 3$ and the excess $\mathrm{NaOH}$ in the traps was titrated back with 0.5 N HCL (Anderson, 1982).

Soil respiration was computed from the rate of $\mathrm{CO} 2-\mathrm{C}$ release during 23days of incubation period (Majumdar et al., 2008). The total amount of $\mathrm{CO} 2-\mathrm{C}$ evolved during the incubation period wastaken as a measure of the Cmin of the soil (Franzluebbers and Arshad, 1996).

\section{Results and Discussion}

Following the objective, the microbial parameters of the soils under forest and arable lands were tested. Analysis of microbial biomass $\mathrm{C}$ indicated highest presence of microorganisms in soils under Kainjal plantation $\left(\bar{x} 63.03 \mathrm{~g} \mathrm{~kg}^{-1}\right)$ followed by Som plantation $\left(\bar{x} 59.64 \mathrm{~g} \mathrm{~kg}^{-1}\right)$.

In forest soil, lowest microbial biomass $\mathrm{C}$ was observed under heterogeneous plantation $\left(\bar{x} 30.22 \mathrm{gkg}^{-1}\right)$. Arable lands observed lowest microbial biomass C ( $\bar{x} 20.96)$ (Fig. 1). However, to understand soil microbial biomass and their relationship to soil $\mathrm{C}$, relative proportion of microbial biomass $\mathrm{C}$ to soil total $\mathrm{C}$ is important. This is known as microbial quotient (MQ).

Figure 2 and Table 1 compared the MQ under different land uses. Surprisingly, it indicated a higher soil MQ under agricultural land in comparison to forest soils, which means amount of soil microbial biomass $\mathrm{C}$ per unit soil $\mathrm{C}$ is more in agricultural soil. This is important but unconventional trend. Possibly, less aggregate occluded $\mathrm{C}$ in agricultural soils in comparison to forest soils resulted more 
available $\mathrm{C}$ as food source to soil microorganisms. Analysis of soil respiration (Table1) showed higher microbial activity in forest soils in comparison to agricultural soils.
Possibly higher $\mathrm{C}$ in forest soil, a food source for soil microorganisms, was responsible for that.

Table.1 Soil microbial biomass $\mathrm{C}$ and soil respiration in forest and agricultural soils Rate of soil respiration (ugCO2-Cgsoil-1day-1)

\begin{tabular}{|c|c|c|c|c|c|c|c|}
\hline \multirow[t]{9}{*}{ Land use } & Type & \multicolumn{2}{|c|}{ Microbial } & \multirow[t]{2}{*}{$3^{\text {rd day }}$} & \multirow[t]{2}{*}{$6^{\text {th }}$ day } & \multirow[t]{2}{*}{$13^{\text {th }}$ day } & \multirow[t]{2}{*}{$23^{\text {rd }}$ day } \\
\hline & & & $\left(\mu \mathrm{g} \mathrm{g}^{-1}\right)$ & & & & \\
\hline & & & 27.03 & 9.0 & 9.0 & 8.8 & 7.4 \\
\hline & & & 42.29 & 9.4 & 9.5 & 9.0 & 8.3 \\
\hline & & Jarul & 74.40 & 9.6 & 9.3 & 9.2 & 7.9 \\
\hline & & & 22.48 & 9.3 & 9.8 & 9.3 & 7.1 \\
\hline & & & 47.52 & 9.8 & 9.8 & 9.4 & 7.5 \\
\hline & Homogenous & Kainjal & 46.30 & 9.4 & 9.2 & 9.3 & 7.2 \\
\hline & & & 79.76 & 9.1 & 8.9 & 8.1 & 7.1 \\
\hline \multirow[t]{15}{*}{ Forest } & & Panisaj & 53.80 & 9.4 & 9.4 & 9.0 & 7.9 \\
\hline & & & 31.85 & 8.8 & 9.3 & 9.0 & 8.0 \\
\hline & & Som & 59.64 & 9.2 & 9.6 & 8.5 & 6.9 \\
\hline & & & 28.37 & 9.2 & 8.5 & 7.5 & 8.4 \\
\hline & Heterogenous & & 17.66 & 9.0 & 9.2 & 7.1 & 7.8 \\
\hline & & & 47.52 & 9.7 & 9.4 & 9.1 & 8.0 \\
\hline & & & 27.33 & 9.3 & 9.4 & 9.3 & 7.8 \\
\hline & Mean of forest & & 43.28 & 9.30 & 9.31 & 8.76 & 7.66 \\
\hline & $\begin{array}{c}\text { SEm }( \pm) \text { of } \\
\text { forest }\end{array}$ & & 4.89 & 0.07 & 0.09 & 0.18 & 0.12 \\
\hline & & & 14.26 & 8.6 & 8.6 & 8.5 & 7.9 \\
\hline & & J-R-F & 15.38 & 8.7 & 8.6 & 8.6 & 8.0 \\
\hline & & & 28.02 & 8.4 & 8.6 & 8.6 & 7.4 \\
\hline & & & 24.69 & 8.2 & 8.7 & 8.5 & 7.8 \\
\hline & & & 18.20 & 8.7 & 8.4 & 8.2 & 7.5 \\
\hline & & & 22.01 & 8.5 & 8.4 & 8.6 & 7.8 \\
\hline \multirow[t]{9}{*}{ Agriculture } & & & 29.65 & 8.4 & 8.6 & 8.2 & 8.0 \\
\hline & & J-R-P & 23.74 & 8.2 & 8.5 & 8.1 & 7.7 \\
\hline & & & 22.56 & 8.3 & 8.6 & 8.2 & 7.5 \\
\hline & & & 12.28 & 8.6 & 8.7 & 8.4 & 7.0 \\
\hline & & & 16.96 & 8.4 & 8.5 & 8.5 & 7.7 \\
\hline & & J-R-M & 18.56 & 8.6 & 8.5 & 8.3 & 7.0 \\
\hline & & & 26.22 & 8.4 & 8.4 & 8.4 & 7.8 \\
\hline & $\begin{array}{c}\text { Mean of } \\
\text { agriculture }\end{array}$ & & 20.96 & 8.46 & 8.55 & 8.39 & 7.62 \\
\hline & $\begin{array}{l}\operatorname{SEm}( \pm) \text { of } \\
\text { agriculture }\end{array}$ & & 1.46 & 0.05 & 0.03 & 0.05 & 0.09 \\
\hline
\end{tabular}




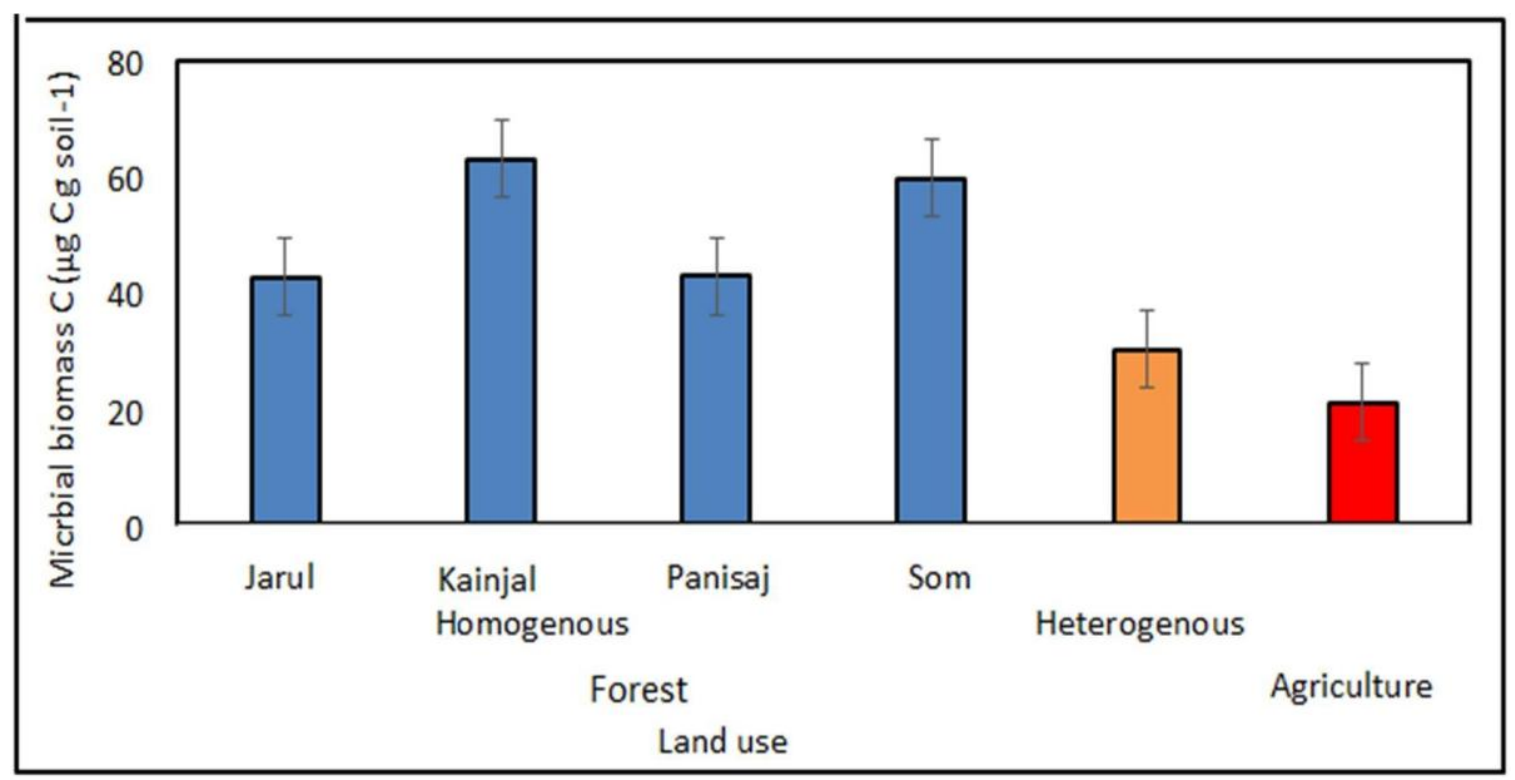

Fig.1 Microbial biomass $\mathrm{C}$ in forest and agricultural soils

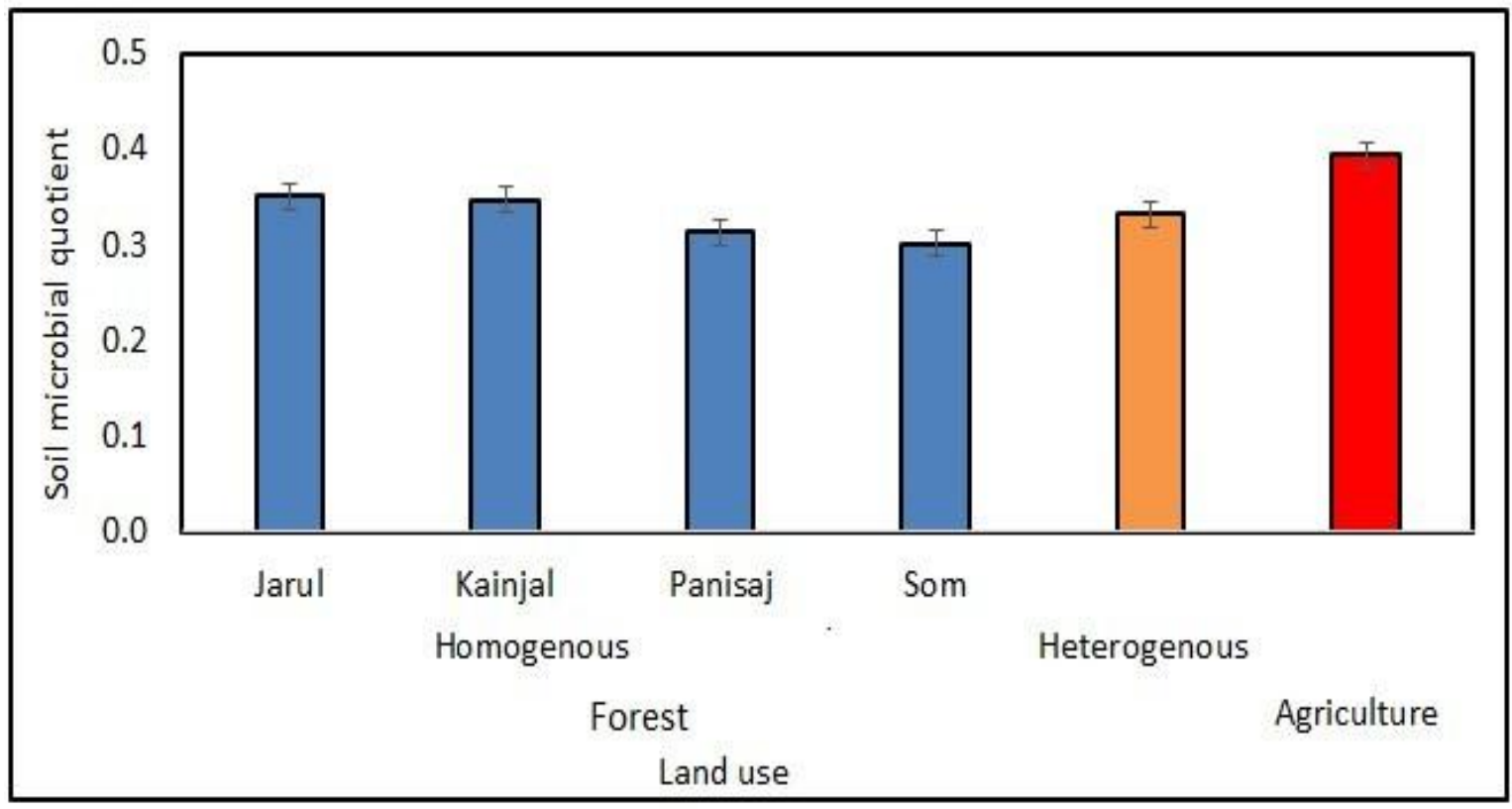

Fig.2 Microbial quotient in forest and agricultural soils

This study highlighted the soil $\mathrm{C}$ dynamics under forest and cultivated land-ecology. Soil microbial parameters were studied as $\mathrm{C}$ cycle and microbial activities are closely related. Soil microbial biomass $\mathrm{C}$ and respiration were higher in forest soils. Possibly, higher $\mathrm{C}$ status of forest soils was the reason. Ratio of microbial biomass $\mathrm{C}$ to soil total $\mathrm{C}$ (microbial quotient) showed higher microbial biomass per unit $\mathrm{C}$ in arable soils. It indicated higher microbial dynamics in agricultural soils per unit soil C.

Possibly, lesser aggregate formation and less protection resulted available $\mathrm{C}$ as food source for microorganisms in agricultural soils. 


\section{References}

Anderson, J.P.E., Armstrong, R.A., Smith, S.N., 1982. Methods to evaluate Pesticide damage to the biomass of the soil microflora. Soil Biology and Biochemistry 13,149-153.

Behera, N., Joshi, S. K., Pati, D.P., 1990. Root contribution to total soil metabolism in a tropical forest soil from Orissa, India. Forest Ecology and Management 36, 125-134.

Brockett, B.F., Prescott, C.E., Grayston, S.J., 2012. Soil moisture is the major factor influencing microbial community structure and enzyme activities across seven biogeoclimatic zones in western Canada. Soil Biology and Biochemistry 44, 9-20.

Brzostek, E.R., Greco, A., Drake, J.E., Finzi, A.C., 2013. Root carbon inputs to the rhizosphere stimulate extracellular enzyme activity and increase nitrogen availability in temperate forest soils. Biogeochemistry 115, 65-76.

Caldwell, B.A., 2005. Enzyme activities as a component of soil biodiversity: a review. Pedobiologia 49, 637-644.

Castro, H., Classen, A.T., Austin, E.E., Norby, R.J., Schadt, C.W., 2010. Soil microbial community responses to multiple experimental climate change drivers. Applied and Environmental Microbiology 76,999-1007.

Frankenberger, W., Dick, W. A., 1983. Relationships between enzyme activities and microbial growth and activity Indices in Soil 1. Soil Science Society of America Journal 47, 945951.

Franzluebbers, A.J., Arshad, M.A., 1996. Soil organic matter pools during early adoption of conservation tillage in north western Canada. Soil Science Society of America journal 60, 1422-1427.

Kaiser, C., Koranda, M., Kitzler, B.,
Fuchslueger, L., Schnecker, J., Schweiger, P., Richter, A., 2010. Belowground carbon allocation by trees drives seasonal patterns of extracellular enzyme activities by altering microbial community composition in a beech forest soil. New Phytologist 187, 843858.

Lange, M., Eisenhauer, N., Sierra, C.A., Bessler, H., Engels, C., Griffiths, R.I., Steinbeiss, S., 2015. Plant diversity increases soil microbial activity and soil carbon storage. Nature communications 6, 6707 .

Majumder, B., Mandal, B., Bandyopadhyay, P.K., 2008. Soil organic carbon poolsand productivity in relation to nutrient management in a 20-year-old rice- berseem agroecosystem. Biology and Fertility of Soils 44,451-461.

Ramirez, K.S., Craine, J.M., Fierer, N., 2012. Consistent effects of nitrogen amendments on soil microbial communities and processes across biomes. Global Change Biology 18, 1918-1927.

Salazar, S., Sánchez, L.E., Alvarez, J., Valverde, A., Galindo, P., Igual, J.M., Santa- Regina, I., 2011. Correlation among soil enzyme activities under different forest system management practices. Ecological Engineering 37, 1123-1131.

Sardans, J., Penuelas, J., 2005. Drought decreases soil enzyme activity in a Mediterranean QuercusilexL. Forest. Soil Biology and Biochemistry 37, 455461.

Sinsabaugh, R.S., 1994. Enzymic analysis of microbial pattern and process. Biology and Fertility of Soils 17, 69-74.

Snajdr, J., Valaskova, V., Merhautova, V., Herinkova, J., Cajthaml, T., Baldrian, P., 2008. Spatial variability of enzyme activities and microbial biomass in the upper layers of Quercus petraea forest 
soil. Soil Biology and Biochemistry 40, 2068-2075.

Srivastava, S.C., Singh, J.S., 1991. Microbial $\mathrm{C}, \mathrm{N}$, and $\mathrm{P}$ in dry tropical forest soils: effects of alternate land-uses and nutrient flux. Soil Biology and
Biochemistry 23, 117-124.

Voroney, R.P., Paul, E.A., 1984. Determination of $\mathrm{kC}$ and $\mathrm{kN}$ insitu for calibration of the chloroform fumigation incubation method. Soil Biology and Biochemistry 16, 9-14.

\section{How to cite this article:}

Munmun Majhi, Deo Kumar, Vivek Kumar, Abhishek Ranjan. 2020. Comparative Study of Soil Microbial Dynamics under Forest and Agricultural Lands of Cooch Behar District of West Bengal, India. Int.J.Curr.Microbiol.App.Sci. 9(04): 2434-2440.

doi: https://doi.org/10.20546/ijcmas.2020.904.292 